\title{
PEMANTAUAN PENURUNAN MUKA TANAH DI KAWASAN WATUKOSEK MENGGUNAKAN METODE SIPAT DATAR
}

\author{
Ira M. Anjasmara, Masrul \\ Jurusan Teknik Geomatika, Fakultas Teknik Sipil dan Perencanaan, \\ Institut Teknologi Sepuluh Nopember Kampus ITS Sukolilo, Surabaya, 60111, Indonesia \\ Email : ira@geodesy.its.ac.id
}

\begin{abstract}
Abstrak
Patahan Watukosek yang terletak di Kabupaten Pasuruan dan Kabupaten Sidoarjo merupakan patahan yang terbentuk sebagai akibat dari proses tumbukan lempeng Eurasia dengan lempeng Australia. Aktifnya patahan ini diyakini men- gakibatkan terjadinya fenomena deformasi vertikal dari permukaan tanah disekitar patahan tersebut. Deformasi vertikal dapat berupa penurunan muka tanah (subsidence) atau kenaikan muka tanah (uplift). Untuk memantau perubahan perg- erakan tinggi muka tanah, salah satu metode yang dapat digunakan adalah pengukuran sipat datar. Sistem tinggi yang digunakan adalah sistem tinggi ortometrik yang bereferensi terhadap geoid.

Dari hasil pengukuran dan pengolahan data yang dilakukan, didapat bahwa terjadi perubahan tinggi muka tanah pada kawasan yang dilewati oleh patahan Watukosek. Pemantauan yang dilakukan selama 2 bulan menunjukkan terjadinya perubahan tinggi muka tanah yang bervariasi pada setiap titiknya. Perubahan tinggi muka tanah paling besar terjadi pada BM PLNG pada perbandingan kala 1 \& kala 2 dengan nilai sebesar $-0,305 \mathrm{~m}$ (subsidence) dan perubahan yang paling kecil terjadi pada BM TTG-1305 pada perbandingan kala 1 \& kala 3 dan kala 2 \& kala 3 , dengan nilai sebesar -0,011 m (subsidence) dan pada perbandingan kala 2 \& kala 3 sebesar 0,011 m (uplift).
\end{abstract}

Kata kunci: Penurunan muka tanah, Patahan Watukosek, Metode sipat datar

\section{PENDAHULUAN}

\section{Latar Belakang}

Indonesia yang terletak pada zona Ring of Fire merupakan daerah / kawasan yang rentan terhadap bencana gempabumi dan gunung api. Salah satu akibat dari bencana tersebut adalah terbentuknya patahan - patahan baru di dalam pulau yang ada. Patahan Watukosek merupakan patahan yang sampai saat ini masih menjadi kontroversi dalam hal pengaktifan kembalinya (reactivation). Mazzini et al. (2007) menyebutkan bahwa pengaktifan kembali patahan Watukosek disebabkan oleh gempabumi yang melanda Yogyakarta pada tahun 2008. Akan tetapi, Abidin et al. (2009) menyanggah pendapat tersebut dengan bukti rekaman berkelanjutan GPS yang menunjukkan pengaktifan kembali Patahan Watukosek terjadi sekitar 3-4 bulan setelah semburan Lumpur sidoarjo pertama terdeteksi (29 Mei 2008).

Akibat dari reaktifasi patahan Watukosek salah sat- unya adalah perubahan tinggi muka tanah di sek- itar wilayah yang dilaluinya. Keaktifan pergerakan dari patahan tersebut juga dipacu oleh beberapa hal seperti pengambilan air tanah yang berlebihan, beban bangunan (settlement), konsolidasi alamiah dari lapisan - lapisan tanah, serta gaya - gaya tektonik.

Lokasi Patahan Watukosek dimulai dari bukit Watukosek ke arah timur memotong sungai Porong. Bukti dari keberadaan patahan Watukosek diku- atkan oleh salah satu bagian bukit yang terpotong memanjang terus ke timur. Patahan Watukosek kurang terdeteksi karena tertutup tanah dan veg- etasi lain. Fitur patahan terlihat kembali di dekat Perumahan Tanggulangin Anggun Sejahtera (TAS), Porong. Patahan Watukosek mempunyai panjang lebih dari $15 \mathrm{~km}$ dan berpotensi aktif dan menimbulkan gempa.

Ada beberapa cara atau metode yang bisa dilakukan untuk mengamati perubahan tinggi muka tanah, diantaranya dengan pengukuran GPS dan pengukuran sipat datar. Dalam penelitian ini, akan digunakan metode pengukuran sipat datar untuk mengamati perubahan tinggi muka tanah yang terjadi di kawasan patahan Watukosek. Metode sipat datar dipilih karena memiliki ketelitian yang lebih baik dibandingkan dengan metode GPS jika dilakukan baik. Tetapi harus diperhatikan juga alat 
dan metode pengambilan data di lapangan yang di gunakan. Dalam penelitian ini, alat yang digunakan adalah waterpass jenis Wild NAK 2 dengan ketelitian $\pm 1 \mathrm{~mm}$

\section{METODOLOGI PENELITIAN}

\section{Lokasi Penelitian}

Penelitian ini dilakukan di Kabupaten Pasuruan dan Sidoarjo. Tepatnya antara $112^{\circ} 5^{\prime}$ dan $112^{\circ}$ $9^{\prime} \mathrm{Bu}$ - jur Timur dan antara $7^{\circ} 3^{\prime}$ dan $7^{\circ} 5^{\prime}$ Lintang Se- latan. Batas sebelah utara adalah Kota Surabaya - - Kabupaten Gresik, sebelah selatan adalah Kabu- paten Malang, sebelah timur adalah Selat Madura - Kabupaten Probolinggo, dan sebelah barat adalah Kabupaten Mojokerto. Lokasi penelitian tersebut dapat dilihat pada Gambar 1.

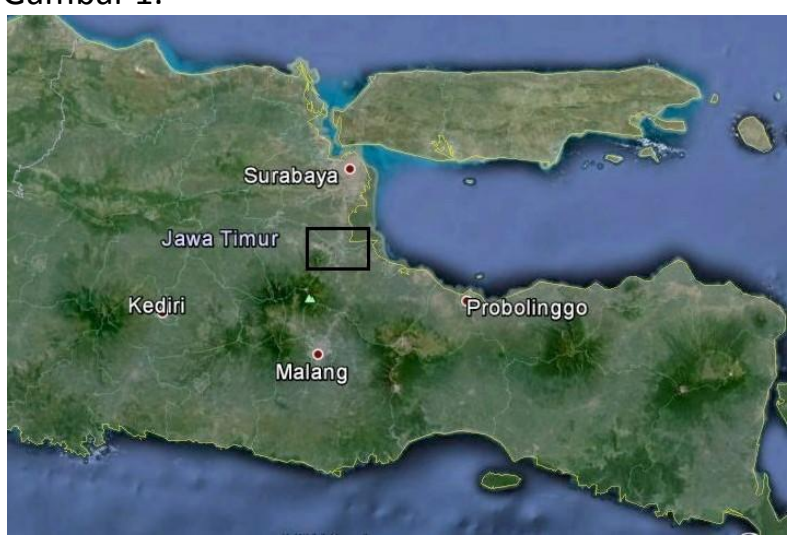

Gambar 1. Lokasi Penelitian (Sumber: Google Earth)

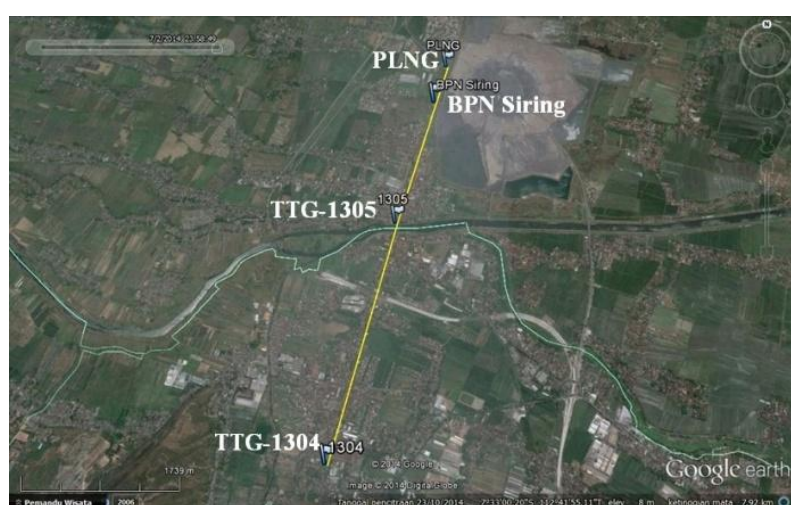

Gambar 2: Sebaran titik-titik pemantauan perubahan tinggi

\section{Tahap Pengolahan Data}

Tahap pengolahan dalam penelitian ini dapat dili- hat pada Gambar 3. Pada tahap pengukuran lapan- gan, pengambilan data dilakukan secara berkala se- banyak 3 kali dengan rentang waktu 20. Sebaran titik-titik pengamatan yang digunakan dapat dilihat pada Gambar 2 .
Pengukuran dimulai pada awal Mei

2014 dan selesai pada akhir Juni 2014. Metode pen- gukuran sipat datar dilakukan dengan cara double stand. Data awal pengukuran akan langsung diolah setiap selesai 1 kala pengukuran.

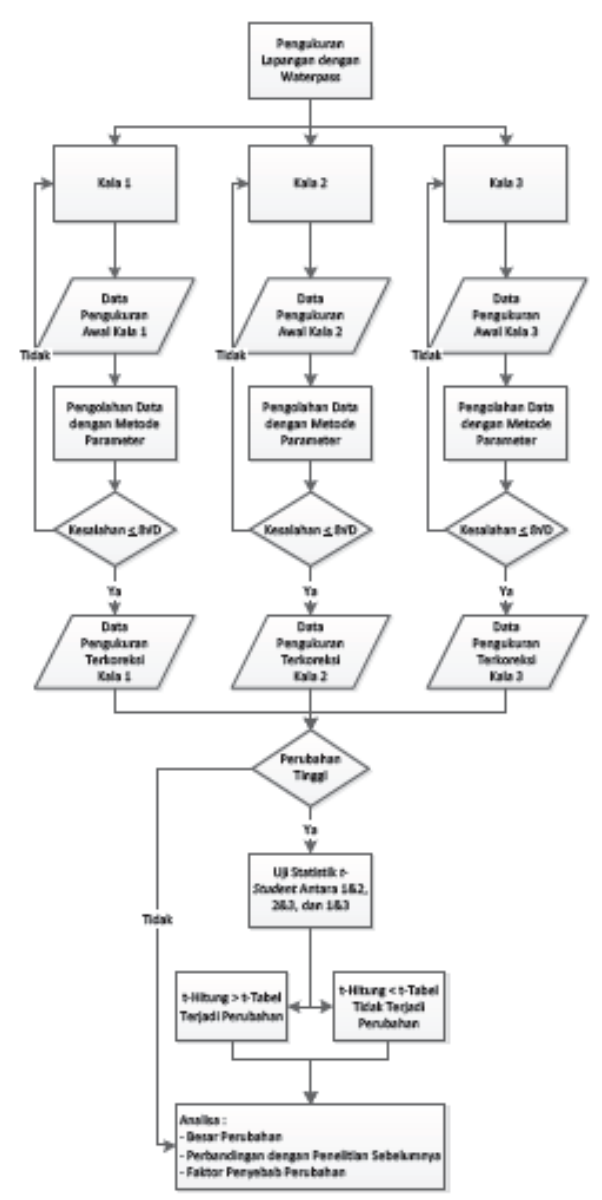

Gambar 3: Diagram Alir Penelitian

Setelah data pengukuran awal didapat, kemudian dilakukan pengolahan data dengan metode Least Square (perataan kuadrat terkecil) menggunakan bantuan software Microsoft Excel dan Matlab R2010a. Dalam hal ini toleransi yang dipakai adalah toleransi orde 2 yaitu $8 \sqrt{D}$, dimana $D$ adalah total jarak pengukuran. Apabila hasil yang didapat tidak memenuhi toleransi, maka dilakukan pengukuran ulang, tetapi apabila memenuhi maka dilanjutkan ke tahap berikutnya. Hasil yang didapat disebut data pengukuran terkoreksi.

Selanjutnya dilakukan perbandingan untuk melihat apakah terjadi perubahan ketinggian atau tidak, jika tidak terjadi perubahan maka langsung menuju ke tahap analisa dan bila terjadi perubahan dilanjutkan ke proses uji statistik. Uji statistik yang di- 
gunakan adalah uji $t$-Student, dengan hipotesa nol jika $t$-Hitung $>t$-Tabel maka terjadi perubahan tinggi dan hipotesa tandingan apabila $t$-Hitung $<t$-Tabel maka tidak terjadi perubahan tinggi.

Analisa yang dilakukan terhadap pergerakan empat BM (Benchmark) yang telah diukur dengan meng- gunakan Waterpass. Akan dilihat apakah masing- masing $B M$ tersebut mengalami penurunan (subsi- dence), kenaikan (uplift), atau tidak mengalami pe- rubahan. Kemudian dilakukan validasi data dengan hasil penelitian lain yang telah dilakukan di titik-titik BM yang sama.

\section{HASIL DAN PEMBAHASAN}

\section{Pengukuran Waterpass}

Pengukuran waterpass bertujuan untuk mendapatkan tinggi titik-titik pengamatan yang bereferensi terhadap geoid (tinggi ortometrik). Pengukuran dilakukan secara berkala untuk mengetahui perubahan tinggi yang terjadi pada setiap BM. Dalam penelitian ini pengukuran dilakukan sebanyak 3 kala dengan rentang waktu 20 hari. Tinggi titik BM TTG-1304 yang dijadikan sebagai acuan dalam menentukan tinggi BM selanjutnya diperoleh dari pengukuran GPS pada bulan April 2014. Karena data tinggi titik yang diperoleh dari pengukuran GPS berupa tinggi yang bereferensi terhadap elipsoida, maka perlu dikonversi menjadi tinggi ortometrik. Data titik-titik pengamatan yang digunakan dalam penelitian ini dapat dilihat pada Tabel 1.

Tabel 1: Koordinat titik-titik pengamatan

\begin{tabular}{llll}
\hline BM & $X(\mathrm{~m})$ & $\mathrm{Y}(\mathrm{m})$ & $\mathrm{Z}(\mathrm{m})$ \\
\hline TTG-1304 & 686567 & 9162606 & 43,299 \\
TTG-1305 & 687353 & 9165632 & - \\
BPN Siring & 687927 & 9167613 & - \\
PLNG & 688092 & 9168181 & - \\
\hline
\end{tabular}

Data ketinggian ( $\mathrm{Z}$ ) yang digunakan hanya data $Z$ pada BM TTG-1304 dikarenakan menurut penelitian-penelitian terdahulu dan juga rekomendasi dari BAPEL BPLS Sidoarjo titik TTG-1304 merupakan titik yang paling stabil dan dapat dijadikan referensi untuk digunakan pada pengukuran leveling.

Setelah pengukuran lapangan dengan alat waterpass WILD NAK 2 didapatkan data awal berupa data beda tinggi tiap BM. Data awal yang didapatkan pada pengukuran kala pertama dapat dilihat pada Tabel 2.

Tabel 2: Data pengukuran beda tinggi antar titik pengamatan pada pengukuran Kala 1

\begin{tabular}{lcc}
\hline \multirow{2}{*}{ BM } & \multicolumn{2}{c}{$\Delta \mathrm{h}(\mathrm{m})$} \\
\cline { 2 - 3 } & Stand 1 & Stand 2 \\
\hline TTG1304 - 1305 & $-4,141$ & 4,137 \\
TTG1305 - BPN & $-6,862$ & 6,865 \\
BPN - PLNG & $-0,844$ & 0,844 \\
\hline
\end{tabular}

Setelah data beda tinggi antar titik didapat, maka berdasarkan data ketinggian (Z) pada BM TTG1304 yang diperoleh dari data GPS bulan April 2014 maka didapat ketinggian pada setiap titik yang digunakan dalam penelitian. Ketinggian setiap titik pada tiap kala pengukuran sebelum dilakukan perataan pa- rameter dapat dilihat pada Tabel 3.

Tabel 3: Tinggi titik-titik pengamatan sebelum dilakukan perataan

\begin{tabular}{llll}
\hline \multirow{2}{*}{ BM } & \multicolumn{3}{c}{ Elevasi $(\mathrm{m})$} \\
\cline { 2 - 4 } & Kala 1 & Kala 2 & Kala 3 \\
\hline TTG-1304 & 43,299 & 43,299 & 43,299 \\
TTG-1305 & 39,159 & 39,142 & 39,142 \\
BPN Siring & 32,297 & 32,011 & 32,255 \\
PLNG & 31,453 & 31,160 & 32,401 \\
\hline
\end{tabular}

\section{Perataan Parameter}

Setelah data awal didapat, dengan menggunakan data ketinggian (Z) pada titik BM TTG-1304 maka didapat ketinggian tiap $B M$, namun ketinggian ini masih harus diratakan dengan melakukan perataan secara parameter. Persamaan umum perataan pa- rameter yang digunakan adalah sebagai berikut (Ghilani, 2010):

$$
W A X=W L+W V
$$

dimana $W$ adalah matriks berat pengamatan, $A$ adalah matriks desain pengukuran, $X$ adalah matriks parameter, $L$ adalah matriks pengamatan, dan $V$ adalah matriks residu. Parameter yang dicari dapat dihitung melalui persamaan berikut:

$$
X=N^{-1}\left(A^{T} W L\right)
$$

dengan $N=A^{T} W A$. 
Matriks berat pengamatan, $W$, yang digunakan dalam penelitian ini disusun berdasarkan jarak pengukuran dari setiap slag yang ada. Untuk kala 1 matriks berat pengamatannya adalah sebagai berikut:

$$
W=\left[\begin{array}{ccccccccc}
1.0000 & 0 & & 0 & 0 & & 0 & 0 & \\
0 & 1.6667 & 0 & 0 & & 0 & 0 & \\
0 & 0 & 5.6667 & 0 & 0 & & 0 \\
0 & 0 & 0 & 5.6667 & 0 & & 0 \\
0 & 0 & 0 & 0 & 1.6667 & 0 \\
0 & 0 & 0 & 0 & 0 & 1.0000
\end{array}\right]
$$

Matriks $\mathrm{N}$ yang didapatkan untuk kala 1 adalah sebagai berikut.

$$
\mathbf{N}=\left[\begin{array}{ccc}
5.0563 & -3.0563 & 0 \\
-3.0563 & 13.7371 & -10.6808 \\
0 & -10.6808 & 10.6808
\end{array}\right]
$$

Setelah nilai $\mathrm{N}$ didapat maka selanjutnya dapat dihitung parameter tinggi yang dicari. Untuk kala 1 didapatkan matriks parameter, $\mathrm{X}$ sebagai berikut.

$$
X=\left[\begin{array}{l}
39.1600 \\
32.2965 \\
31.4525
\end{array}\right]
$$

Matriks residual untuk kala 1 adalah sebagai berikut.

$$
\mathrm{V}=\left[\begin{array}{c}
0.0020 \\
-0.0015 \\
0.0000 \\
-0.0000 \\
-0.0015 \\
0.0020
\end{array}\right]
$$

Setelah nilai dari matriks residual didapat maka dilakukan penghitungan standar deviasi untuk pen- gukuran kala 1, dengan hasil sebagai berikut.

$$
S D=0.0022 \mathrm{~m}
$$

Dengan proses yang sama, dilakukan juga proses pengolahan data untuk pengukuran kala 2 dan kala 3. Standar deviasi untuk ketiga kala pengukuran yang telah dilakukan dapat dilihat pada Tabel 4 .

Tabel 4: Standar deviasi dari ketiga Kala pengukuran

\begin{tabular}{ccc}
\hline Kala $1(\mathrm{~m})$ & Kala $2(\mathrm{~m})$ & Kala $3(\mathrm{~m})$ \\
\hline 0.0022 & 0.0035 & 0.0025
\end{tabular}

\section{Analisa Toleransi Pengukuran}

Seperti dijelaskan sebelumnya, toleransi kesalahan yang diperbolehkan dalam penelitian ini adalah $8 \sqrt{D}$. Total jarak pengukuran dalam penelitian ini adalah 5,819 $\mathrm{km}$, sehingga kesalahan maksi- mal yang diperbolehkan adalah sebesar 19,267 mm. Dari Tabel 4 dapat dilihat bahwa ketiga kala pen- gukuran memiliki kesalahan yang masih memenuhi toleransi yang diperbolehkan.

Setelah semua data memenuhi toleransi, maka data dapat digunakan sehingga setelah dilakukan per- ataan parameter didapat elevasi/ketinggian akhir dari setiap BM yang dapat dilihat pada Tabel 5.

Tabel 5: Tinggi titik-titik pengamatan setelah dilakukan perataan

\begin{tabular}{llll}
\hline \multirow{2}{*}{ BM } & \multicolumn{3}{c}{ Elevasi $(\mathrm{m})$} \\
\cline { 2 - 4 } & Kala 1 & Kala 2 & Kala 3 \\
\hline TTG-1304 & 43,299 & 43,299 & 43,299 \\
TTG-1305 & 39,160 & 39,138 & 39,149 \\
BPN Siring & 32,297 & 32,002 & 32,266 \\
PLNG & 31,453 & 31,148 & 31,413 \\
\hline
\end{tabular}

\section{Analisa Standar Deviasi Pengukuran}

Dalam penelitian ini, uji statistik yang digunakan adalah uji $t$-Student. Uji $t$-Student dilakukan untuk mengetahui apakah terjadi perbedaan tinggi yang nyata atau hanya karena kebetulan. Karena pen- gukuran tinggi dilakukan dalam 3 kala, maka dapat dilakukan 3 kali uji statistik. Uji statistik yang pertama yaitu antara data hasil pengukuran kala 1 dan kala 2, yang kedua antara data hasil pengukuran kala 2 dan kala 3, dan yang ketiga antara data hasil pengukuran kala 1 dan kala 3. Hasil uji t-Student yang didapat disajikan pada Tabel 6, Tabel 7, dan Tabel 8. 
Tabel 6: Hasil Uji t-Student Antara Pengukuran Kala 1,2

\begin{tabular}{llllr}
\hline \multirow{2}{*}{ BM } & \multicolumn{2}{c}{ Tinggi $(\mathrm{m})$} & \multirow{2}{*}{$d(\mathrm{~m})$} & $d^{2}\left(\mathrm{~m}^{3}\right)$ \\
\cline { 2 - 3 } & Kala 1 & Kala 2 & & \\
\hline TTG-1304 & 43,299 & 43,299 & 0,000 & 0,000 \\
1305 & 39,160 & 39,138 & $-0,022$ & 0,001 \\
BPN Siring & 32,297 & 32,002 & $-0,295$ & 0,087 \\
PLNG & 31,453 & 31,148 & $-0,305$ & 0,093 \\
\hline$\Sigma$ & & & $-0,622$ & 0,180 \\
\hline$t$-Hitung & & & & $-1,864$ \\
Df & & & 3 \\
Level Signifikan 10\% ( $t$-Tabel) & & 1,638 \\
\hline
\end{tabular}

Tabel 7: Hasil Uji t-Student Antara Pengukuran Kala 2 \& 3

\begin{tabular}{llllr}
\hline \multirow{2}{*}{ BM } & \multicolumn{2}{c}{ Tinggi $(\mathrm{m})$} & \multirow{2}{*}{$d(\mathrm{~m})$} & $d^{2}\left(\mathrm{~m}^{3}\right)$ \\
\cline { 2 - 3 } & Kala 2 & Kala 3 & & \\
\hline TTG-1304 & 43,299 & 43,299 & 0,000 & 0,000 \\
1305 & 39,138 & 39,149 & 0,011 & 0,000 \\
BPN Siring & 32,002 & 32,266 & 0,264 & 0,070 \\
PLNG & 31,148 & 31,413 & 0,265 & 0,070 \\
\hline$\Sigma$ & & & $-0,540$ & 0,140 \\
\hline$t$-Hitung & & & & $-1,805$ \\
Df & & & 3 \\
Level Signifikan 10\% (t-Tabel) & & 1,638 \\
\hline
\end{tabular}

Tabel 8: Hasil Uji t-Student Antara Pengukuran Kala 1 \& 3

\begin{tabular}{llllr}
\hline \multirow{2}{*}{ BM } & \multicolumn{2}{c}{ Tinggi $(\mathrm{m})$} & \multirow{2}{*}{$d(\mathrm{~m})$} & \multirow{2}{*}{$d^{4}\left(\mathrm{~m}^{3}\right)$} \\
\cline { 2 - 3 } & Kala 1 & Kala 3 & & \\
\hline TTG-1304 & 43,299 & 43,299 & 0,000 & 0,000 \\
1305 & 39,160 & 39,149 & $-0,011$ & 0,000 \\
BPN Siring & 32,297 & 32,266 & $-0,031$ & 0,001 \\
PLNG & 31,453 & 31,413 & $-0,040$ & 0,002 \\
\hline$\Sigma$ & & & $-0,082$ & 0,003 \\
\hline$t$-Hitung & & & $-2,275$ \\
Df & & & 3 \\
Level Signifikan 10\% (t-Tabel) & & 1,638 \\
\hline
\end{tabular}

Berdasarkan hasil uji statistik $t$-Student yang telah dilakukan terlihat bahwa pada pengujian untuk pengukuran kala $1 \& 2$ terjadi perubahan ketinggian pada level signifikan $(\alpha) 10 \%$, pada uji statistik $t$-Student yang kedua untuk pengukuran kala 2 \& 3 juga terjadi perubahan pada level signifikan $(\alpha)$ $10 \%$, dan begitu juga pada uji statistik $t$-Student yang ketiga untuk pengukuran kala 1 \& 3 juga terjadi perubahan pada level signifikan $(\alpha) 10 \%$.

\section{Analisa Perubahan Tinggi}

Berdasarkan hasil pengolahan data yang telah dilakukan, dapat dilihat bahwa terjadi perubahan ketinggian pada benchamark (BM) yang diukur dengan menggunakan alat waterpass (lihat Tabel 9). Dari Tabel 9 dapat dilihat bahwa terjadi perubahan ketinggian pada setiap kala pengukuran, dimana perubahan yang terjadi pada setiap titik berbedabeda.

Perubahan yang terjadi pada perbandingan kala 1 dan kala 2 menunjukkan terjadinya subsidence yaitu terjadinya penurunan ketinggian pada semua titik $\mathrm{BM}$ yang diamati. Besarnya penurunan tinggi yang terjadi bervariasi, pada BM 1305 terjadi penurunan sebesar $2,2 \mathrm{~cm}$, pada BM BPN Siring terjadi penurunan sebesar $29,5 \mathrm{~cm}$, dan pada BM PLNG terjadi penurunan yang paling besar yaitu $30,5 \mathrm{~cm}$.

Tabel 9: Perubahan Ketinggian BM Selama 2 Bulan Pengamatan

\begin{tabular}{llll}
\hline \multirow{2}{*}{ BM } & \multicolumn{3}{c}{ Perubahan tinggi $(\mathrm{m})$} \\
\cline { 2 - 4 } & Kala 1-2 & Kala 1-3 & Kala 2-3 \\
\hline TTG-1304 & 0,000 & 0,000 & 0,000 \\
TTG-1305 & $-0,022$ & $-0,011$ & 0,011 \\
BPN Siring & $-0,295$ & $-0,031$ & 0,264 \\
PLNG & $-0,305$ & $-0,040$ & 0,265 \\
\hline
\end{tabular}

Pada perbandingan pengukuran kala 1 dan 3 juga menunjukkan penurunan, namun tidak terlalu signifikan dibanding dengan perbandingan kala 1 dan kala 3. Pada BM 1305 terjadi penurunan sebesar 1,1 cm, pada BM BPN Siring terjadi penurunan sebesar $3,1 \mathrm{~cm}$, dan pada BM PLNG terjadi penurunan sebesar $4 \mathrm{~cm}$.

Perbedaan terjadi pada perbandingan pengukuran kala 2 dan 3 dimana tderjadi kenaikan pada semua titik BM yang diamati. Pada BM 1305 terjadi ke- naikan sebesar $1,1 \mathrm{~cm}$, pada BM BPN Siring terjadi kenaikan sebesar 26,4 $\mathrm{cm}$, dan pada BM PLNG ter- jadi kenaikan sebesar $26,5 \mathrm{~cm}$.

Dari 3 kali perbandingan yang dilakukan dapat dilihat terjadinya perubahan ketinggian pada semua BM, namun besaran perubahannya tidak sama. Dari 3 kala pengukuran yang dilakukan dapat dikatakan bahwa telah terjadi perubahan 
ketinggian pada se- mua BM yang diamati. Akan tetapi hasil ini hanya didapat dari 3 periode pengukuran, untuk mendap- atkan hasil yang lebih maksimal terkait perubahan ketinggian yang terjadi dapat dilakukan pengukuran lebih dari 3 kali, misalnya dilakukan pengukuran selama 1 tahun atau lebih.

Perubahan tinggi muka tanah yang terjadi ini juga sejalan dengan penelitian sebelumnya yang dilakukan pada bulan Maret - Mei 2014 oleh Pribadi (2014) dan Rochman (2014) dengan metode yang berbeda. Dalam Pribadi (2014) pengamatan dilakukan dengan menggunakan data satelit Global Positioning System (GPS), sedangkan dalam Rochman (2014) menggunakan data satelit Global Positioning System (GPS) dan VLF-EM. Keduanya menunjukkan perubahan muka tanah yang berbeda-beda, berikut merupakan data perubahan muka tanah yang diwakili oleh BM yang juga digu- nakan oleh pengukuran sebelumnya.

Tabel 10: Data GPS Ketinggian BM Maret - Mei 2014 (Pribadi, 2014)

\begin{tabular}{llll}
\hline \multirow{2}{*}{ BM } & \multicolumn{3}{c}{ Perubahan tinggi (m) } \\
\cline { 2 - 4 } & Kala 1 & Kala 2 & Kala 3 \\
\hline 1304 & 43,258 & 43,299 & 43,262 \\
1305 & 38,992 & 39,024 & 39,049 \\
BPN Siring & - & - & - \\
PLNG & 31,408 & 31,348 & 31,306 \\
\hline
\end{tabular}

Tabel 11: Data GPS Ketinggian BM Maret-Mei 2014 (Rochman, 2014)

\begin{tabular}{llll}
\hline \multirow{2}{*}{ BM } & \multicolumn{3}{c}{ Perubahan tinggi (m) } \\
\cline { 2 - 4 } & Kala 1 & Kala 2 & Kala 3 \\
\hline 1304 & 44,660 & 44,635 & 44,606 \\
1305 & 40,387 & 40,381 & 39,786 \\
BPN Siring & 32,926 & 32,786 & 32,912 \\
PLNG & - & - & - \\
\hline
\end{tabular}

Pada data ketinggian Maret - Mei 2014 (Pribadi, 2014), data untuk BM BPN Siring kosong dikarenakan pada penelitian tersebut BM BPN Siring tidak digunakan, begitu juga pada data ketinggian MaretMei 2014 (Rochman, 2014) data BM PLNG tidak ada dikarenakan penelitian tersebut tidak menggunakan BM PLNG.

Dari kedua penelitian terdahulu terlihat bahwa meskipun dengan metode yang berbeda telah ter- jadi perubahan tinggi muka tanah di titik-titik pengamatan. Namun jika dibandingkan, perubahan tinggi yang terjadi dalam penelitian ini mempunyai nilai yang lebih besar. Perbedaan tinggi yang terjadi dengan pengamatan siapat datar dapat dilihat pada Tabel 12.

Tabel 12: Data Waterpass Ketinggian BM Mei-Juni 2014

\begin{tabular}{llll}
\hline \multirow{2}{*}{ BM } & \multicolumn{3}{c}{ Perubahan tinggi $(\mathrm{m})$} \\
\cline { 2 - 4 } & Kala 1 & Kala 2 & Kala 3 \\
\hline 1304 & 43,299 & 43,299 & 43,299 \\
1305 & 39,16 & 39,138 & 39,149 \\
BPN Siring & 32,297 & 32,002 & 32,266 \\
PLNG & 31,453 & 31,148 & 31,413 \\
\hline
\end{tabular}

Banyak hal yang menyebabkan perbedaan perubahan ketinggian yang terjadi. Pertama dari datum yang digunakan, metode menggunakan GPS menggunakan datum ellipsoid sedangkan metode dengan menggunakan alat waterpass menggunakan da- tum geoid. Yang kedua dari titik referensi yang di- gunakan, dengan metode menggunakan GPS referensi yang digunakan yaitu titik CORS ITS Surabaya sedangkan dengan metode pengukuran sipat datar referensi yang digunakan merupakan titik TTG-1304 yang terletak di Japanan dimana dalam pengukuran GPS titik ini mengalami perubahan selama 3 bulan pengamatan. Dan yang ketiga faktor yang menyebabkan perbedaan perubahan tinggi muka tanah yang terjadi adalah waktu pengamatan yang tidak sama.

\section{Penyebab Penurunan Muka Tanah}

Patahan Watukosek dan Lumpur Sidoarjo diduga menjadi penyebab terjadinya perubahan tinggi muka tanah yang terjadi di lokasi penelitian. Namun dengan adanya perbedaan pendapat mengenai po- sisi pasti Patahan Watukosek dan sangat sedikitnya data yang digunakan (hanya data pengukuran waterpass), sangat sulit untuk mengetahui penyebab pasti perubahan tinggi muka tanah di daerah penelitian.

Untuk mengetahui penyebab pastinya dibutuhkan data pendukung lain seperti data volume lumpur di Lumpur Sidoarjo selama masa penelitian, data kepadatan jalan raya sekitar penelitian mengingat daerah penelitian juga merupakan kawasan yang cukup padat aktifitas jalan rayanya, data perubahan struktur geologi 
yang terjadi selama masa peneli- tian, dan juga data pengambilan air tanah oleh warga sekitar.

Menurut Whittaker and Reddish (1989) salah satu penyebab penurunan muka tanah secara umum adalah pengambilan air tanah (groundwater extraction), dimana pengambilan air tanah secara besar- besaran yang melebihi kemampuan pengambilannya akan mengakibatkan berkurangnya jumlah air tanah pada suatu lapisan akuifer. Hilangnya air tanah mengakibatkan terjadinya kekosongan pori-pori tanah sehingga tekanan hidrostatis di bawah permukaan tanah berkurang sebesar hilangnya air tanah tersebut, selanjutnya akan terjadi pemampatan lapisan akuifer. Oleh sebab itu data - data pendukung tersebut sangat penting untuk mengetahui penyebab pasti dari perubahan muka tanah yang terjadi di sekitar patahan Watukosek.

\section{PENUTUP}

\section{Kesimpulan dan Saran}

Dari hasil pemantauan dan analisa perubahan beda tinggi di titik-titik pengamatan selama 3 kala, dapat diambil kesimpulan sebagai berikut:

1. Telah terjadi perubahan tinggi muka tanah pada kawasan Patahan Watukosek berdasarkan pada titik-titik BM yang diamati. Dari 3 perbandingan yang dilakukan menunjukkan semua BM men- galami perubahan ketinggian. Besarnya peruba- han yang terjadi selama 2 bulan pengukuran (Mei-Juni 2014) bervariasi, dimana perubahan tinggi yang paling besar terjadi pada BM PLNG pada perbandingan 1 dan 2 dengan nilai $-0,305 \mathrm{~m}$ (terjadi subsidence) dan perubahan yang paling kecil terjadi pada BM TTG-1305 pada perbandingan 1 dan 3 serta 2 dan3, dimana pada perbandin- gan 1 dan 3 mengalami perubahan sebesar -0,011 m (subsidence) dan pada perbandingan 2 dan 3 sebesar 0,011 m (uplift).

2. Penyebab perubahan tinggi muka tanah selama pengukuran belum dapat dipastikan dikarenakan data yang digunakan hanya data pengukuran sipat datar. Untuk melakukan analisa lebih dalam dibutuhkan data pendukung lain seperti data volume lumpur Lumpur Sidoarjo selama penga- matan, data kepadatan jalan raya, perubahan struktur geologi dan data pengambilan air tanah.

\section{Saran}

Untuk penelitian selanjutnya, saran yang dapat diberikan adalah sebagai berikut:

1. Diperlukan data tambahan untuk menganalisis perubahan yang terjadi pada BM yang diamati seperti perubahan struktur geologi, data penggunaan air oleh masyarakat sekitar, data kepadatan jalan disekitar titik BM, data perubahan struk- tur geologi, dan data volume lumpur pada saat melakukan penelitian.

2. Untuk mendapatkan data yang lebih akurat, perlu dilakukan pengukuran secara berkelanjutan (con- tinuing). Dalam hal ini pengukuran tidak hanya di- lakukan selam 3 kala, melainkan harus lebih mis- alnya selama 1 tahun dengan rentang waktu 1 bu- lan. Hal ini dapat memberikan data yang lebih akurat dalam melakukan analisa apakah peruba- han yang terjadi selalu mengalami penurunan, kenaikan, atau bervariasi.

\section{DAFTAR PUSTAKA}

Abidin, H. Z., R. J. Davies, M. A. Kusuma, H. Andreas, and T. Deguchi. 2009. Subsidence and uplift of Sidoarjo (East Java) due to the eruption of the Lusi mud volcano (2006-present). Environmental Ge- ology, 57(4):833-844.

Ghilani, C. D. 2010. Adjustment Computation Spatial Data Analysis, $5^{\text {th }}$ Ed. John Wiley \& Son Inc.

Mazzini, A., H. Svensen, G. Akhmanov, S. Aloisi, G.and Planke, A. Malthe-Sørenssen, and B. Istadi. 2007. Triggering and dynamic evolution of the LUSI mud volcano, Indonesia. Earth and Planetary Science Letters, 261(3-4):375-388.

Pribadi, W. 2014. Analisa Penurunanan Tanah (Landsubsidence) Pada Daerah Semburan Lumpur Sidoarjo Dengan Data Satelit Global Positioning System (GPS). Master's thesis, Jurusan Magis- ter Teknik Geomatika, Institut Teknologi Sepuluh Nopember. 
Rochman, J. P. G. N. 2014. Analisa Penurunanan Tanah (Landsubsidence) Pada Daerah Semburan Lumpur Sidoarjo Dengan Data Satelit Global Po- sitioning System (GPS). Master's thesis, Jurusan Teknik Geomatika, Institut Teknologi Sepuluh Nopember.

Whittaker, B. and D. Reddish. 1989. Subsidence: Oc- currence, Prediction and Control. Elsevier 